\title{
Commentary: The unknown fact about surfactant
}

\author{
Yizhan Guo, MD, and Alexander Sasha Krupnick, MD
}

\author{
From the Department of Surgery, University of Virginia School of Medicine, Charlottesville, Va; and the Carter \\ Center for Immunology, University of Virginia School of Medicine, Charlottesville, Va. \\ Disclosures: Authors have nothing to disclose with regard to commercial support. \\ Received for publication Jan 22, 2019; accepted for publication Jan 22, 2019; available ahead of print March 4, \\ 2019. \\ Address for reprints: Alexander Sasha Krupnick, MD, University of Virginia, PO Box 800679, Charlottesville, VA \\ 22908 (E-mail: sashak@ virginia.edu). \\ J Thorac Cardiovasc Surg 2019;157:2118 \\ 0022-5223/ $\$ 0.00$ \\ Published by Elsevier Inc. on behalf of The American Association for Thoracic Surgery \\ https://doi.org/10.1016/j.jtcvs.2019.01.083
}

The use of corticosteroids has become an almost unavoidable aspect of all solid-organ transplantation, including that of the lungs. Steroid-sparing immunosuppression protocols are rarely used today, despite copious data that long-term steroid use is associated with osteoporosis, cataracts, diabetes, hypertension, and hypercholesterolemia. ${ }^{1}$ All these counterproductive side effects diminish the qualitative and quantitative benefits of solid-organ transplantation. In the current issue of the Journal, Aramini and colleagues $^{2}$ from D'Ovidio's lung transplant program in Columbia University further demonstrate that corticosteroids alter the levels of surfactant proteins in donor lungs. Surfactant levels play a critical role in pulmonary function. This is emphasized by the critical role of surfactant replacement in treating premature neonates. ${ }^{3}$ Surfactant levels also contribute to important aspects of the immunologic defense mechanism in the lung, ${ }^{4}$ a process critical to the already immunosuppressed graft recipient.

D'Ovidio's group ${ }^{2}$ demonstrate differential surfactant protein expression according to the genetic polymorphisms, whether in an epithelial cell line with a rare surfactant protein genotype or in human lung tissue. Specifically, they demonstrate, by using the novel method of analysis of precision cut slices of donor lung tissue, that those with the surfactant protein $\mathrm{A} 2$ variant $1 \mathrm{~A}^{0}$ have increased expression of surfactant when treated with steroids. These in vitro pharmacogenetic findings support previous observations from D'Ovidio's group, in the clinical arena, which documented significantly greater surfactant protein A expression in donor lungs carrying the $1 \mathrm{~A}^{0}$ variant before implantation when donor organs are under the influence of large steroid treatment. Further, the $1 \mathrm{~A}^{0}$ variant within the context of lung transplantation consistently showed a protective effect with better outcomes. ${ }^{5,6}$

Although this issue is not directly explored in the article of Aramini and colleagues, ${ }^{2}$ it is evident to the thoracic surgeon that increased expression of surfactant may in and of itself lead to pathology such as alveolar proteinosis. ${ }^{7}$ These data thus further confound the role of non-high dose

\section{References} Res. 2016;17:66. $1419-21$.

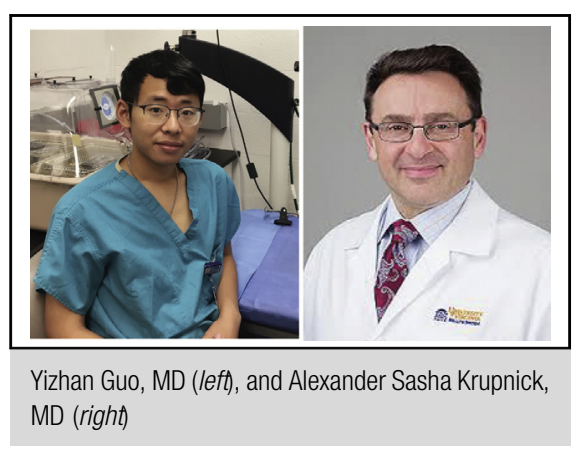

\section{Central Message}

Corticosteroids may affect lung surfactant expression, with inherited surfactant subtype polymorphisms playing a key role. This may result in unpredictable side effects in lung allograft recipients.

See Article page 2109

corticosteroid use for both induction and maintenance immunosuppression in the lung allograft recipient. Such data also support the argument for the development of lung-specific immunosuppression that takes advantage of unique inflammatory feedback loops evident in that organ, ${ }^{8,9}$ as well as of the donor's specific pharmacogenetics.

1. Baraldo M, Gregoraci G, Livi U. Steroid-free and steroid withdrawal protocols in heart transplantation: the review of literature. Transpl Int. 2014;27:515-29.

2. Aramini B, Geraghty P, Lederer D, Costa J, DiAngelo SL, Floros J, et al. Surfactant proteins A and D polymorphisms and methylprednisolone pharmacogenetics in donor lungs. J Thorac Cardiovasc Surg. 2019;157:2109-17.

3. Polin RA, Carlo WA; Committee on Fetus and Newborn; American Academy of Pediatrics. Surfactant replacement therapy for preterm and term neonates with respiratory distress. Pediatrics. 2014;133:156-63.

4. Carreto-Binaghi LE, Aliouat el M, Taylor ML. Surfactant proteins, SP-A and SP$\mathrm{D}$, in respiratory fungal infections: their role in the inflammatory response. Respir

5. D’Ovidio F, Kaneda H, Chaparro C, Mura M, Lederer D, Di Angelo S, et al. Pilot study exploring lung allograft surfactant protein A (SP-A) expression in association with lung transplant outcome. Am J Transplant. 2013;13:2722-9. Erratum in: Am J Transplant. 2014;14:496.

6. Aramini B, Kim C, Diangelo S, Petersen E, Lederer DJ, Shah L, et al. Donor surfactant protein D (SP-D) polymorphisms are associated with lung transplant outcome. Am J Transplant. 2013;13:2130-6.

7. Huizar I, Kavuru MS. Alveolar proteinosis syndrome: pathogenesis, diagnosis, and management. Curr Opin Pulm Med. 2009;15:491-8.

8. Witt CA, Puri V, Gelman AE, Krupnick AS, Kreisel D. Lung transplant immunosuppression-time for a new approach? Expert Rev Clin Immunol. 2014;10:

9. Onyema OO, Guo Y, Wang Q, Stoler MH, Lau C, Li K, et al. Eosinophils promote inducible NOS-mediated lung allograft acceptance. JCI Insight. 2017;2:e96455. 